\title{
Endogenous pH, Titratable Acidity and Total Soluble Solid Content of Mouthwashes Available in the Brazilian Market
}

\author{
Alessandro Leite Cavalcantia \\ lanny Alves Ramos ${ }^{b}$ \\ Rafaela Bastos Leite ${ }^{b}$ \\ Mariana da Costa Oliveira ${ }^{b}$ \\ Karynna de Melo Menezes ${ }^{b}$ \\ Lígia Virgínio Fernandes ${ }^{b}$ \\ Ricardo Dias de Castroc \\ Fernando Fernandes Vieira ${ }^{d}$
}

\section{ABSTRACT}

Objectives: To evaluate in vitro the endogenous $\mathrm{pH}$, titratable acidity and total soluble solid content (TSSC) of mouthwashes available in the Brazilian market.

Methods: The study sample was composed of 10 commercial brands of mouthwashes based on dif-

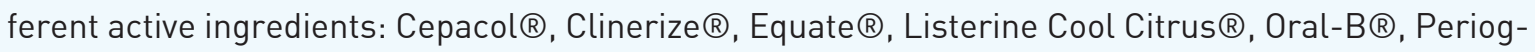
$\operatorname{ard} \circledast$, Peroxy $(\AA$, Plax Overnight $\circledast$, Prevident $220 \AA$ and Sanifill $\circledast$. The experiments were performed in triplicate. The endogenous $\mathrm{pH}$ was evaluated by potentiometry, titratable acidity was evaluated by the addition of $0.1 \mathrm{~N} \mathrm{KOH}$ increments to the mouthwashes, and TSSC readings were performed by Brix refractometry using the Abbé refractometer.

Results: pH values ranged from 3.56 (Peroxyl $\circledast$ ) to 7.43 (Cepacol $($ ) and three mouthwashes presented pHs below 5.5. The titratable acidity values ranged from 0.007 (Periograd $\circledast$ ) to 0.530 (Previ$\operatorname{dent}\left({ }^{8}\right)$. Oral $B \circledast$ and Clinerize ${ }^{\circledR}$ presented the lowest $(4.7 \%)$ and the highest $(23.70 \%)$ TSSC, respectively.

Conclusions: Some of the mouthwashes evaluated in this study presented low endogenous $\mathrm{pH}$, even below the critical value for enamel dissolution $(\mathrm{pH}<5.5)$, high titratable acidity and high TSSC, and may be potentially erosive to the dental tissues if not properly used. (Eur J Dent 2010;4:156-159)

Key words: Mouthwashes; Hydrogen-Ion concentration; Dental plaque; Tooth erosion.

- a DS, MSc, PhD, Professor, Department of Pediatric Dentistry, School of Dentistry, State University of Paraiba, Campina Grande, PB, Brazil.

b Undergraduate student, School of Dentistry, State University of Paraíba, Campina Grande, Brazil. DDS, MSc, PhD Student, Paraiba Federal University, João Pessoa, PB, Brazil.

4 PhD, Professor, Department of Analytical Chemistry, School of Chemistry, State University of Paraiba, Campina Grande, PB, Brazil.

- Corresponding author: Alessandro Leite Cavalcanti Avenida Manoel Moraes, 471/802 - Manaíra 58038-230 João Pessoa, PB, Brasil E-mail: dralessandro@ibest.com.br

\section{INTRODUCTION}

The control of dental biofilm is one of the cornerstones of preventive dentistry and can be achieved by mechanical means, use of chemical agents, or a combination of the two. ${ }^{1}$ Mouthwashes are used as adjuvant agents in daily oral hygiene routine, aiding in the chemical control of dental biofilm. In Brazil, most mouthwashes are freely available at pharmacies, drugstores, supermarkets, and other commercial establishments and usually do not require a prescription from a dentist, making these products readily available 
to children and adults. The indiscriminate use of mouthwashes by the general population has generated concern because the presence of acid components in their formulations could make the products potentially erosive to hard dental tissue over time. ${ }^{2}$ Dental erosion is the progressive and irreversible loss of tooth enamel as a result of chemical processes not involving bacterial action. ${ }^{3}$ Previous studies have demonstrated that several mouthwashes available in the Brazilian ${ }^{2,4}$ and UK ${ }^{5}$ markets present low endogenous $\mathrm{pH}$. A pH equal to or less than 5.5 is traditionally considered critical for enamel dissolution, although mineral loss may begin at higher $\mathrm{pH}^{6}{ }^{6}$

The purpose of this study was to evaluate the endogenous $\mathrm{pH}$, titratable acidity, and total soluble solid content ( ${ }^{\circ} \mathrm{Bx}$ ) of mouthwashes available in the Brazilian market.

\section{MATERIALS AND METHODS}

Ten commercial brands of mouthwashes comprising various active ingredients were selected for this study (Table 1). The products were evaluated in a randomized experiment, with 3 repetitions for each sample, with values averaged to provide a single value per sample. Data were collected by a single calibrated examiner (Kappa=0.83) and recorded in study-specific charts. The endogenous $\mathrm{pH}$ of each mouthwash was measured immediately after package was opened at room temperature $\left(20^{\circ} \mathrm{C}\right)$ using a $\mathrm{pH}$ meter (TEC-2; Tecnal, Sion Paulo, SP, Brazill accurate to $0.1 \mathrm{~mm}$. Titratable acidity was measured according to the method adopted by the Association of Official Analytical Chemists, that is, the amount of $0.1 \mathrm{~N}$ potassium hydroxide $(\mathrm{KOH})$ solution needed for the product to reach $\mathrm{pH}$ equal to or greater than neutral $\mathrm{pH}$. An Abbe refractometer (PZO-RL1, Warszawa, Poland) was used to measure ${ }^{\circ} \mathrm{Bx}$. The equipment was calibrated with deionized water before samples were measured. Mean values and standard deviations were analyzed statistically using SPSS statistical software (SPSS Inc., Chicago, IL, USA).

\section{RESULTS}

Distribution of the mouthwashes according to mean values and standard deviations is presented in Table 2. pH values ranged from 3.56 (Peroxyl) to 7.43 (Cepacol), and three mouthwashes (Clinerize, Listerine Cool Citrus, and Peroxyl) had pH less than the critical value of 5.5 , thus classified as potentially erosive. Titratable acidity values ranged from 0.007 (Periograd $\AA$ ) to 0.530 (Prevident $\AA$ ). Oral $B \circledR$ and Clinerize ${ }^{\circledR}$ demonstrated the lowest $(4.7 \%)$ and the highest $(23.70 \%)^{\circ} \mathrm{Bx}$, respectively.

\section{DISCUSSION}

Mouthwashes have been used for centuries for medicinal and cosmetic purposes, but it is only in recent years that the rationale for use of the active ingredients of these products has been subject to scientific research and clinical trials. ${ }^{7}$ Based on studies published in the Brazilian ${ }^{2,4}$ and international ${ }^{5,8-10}$ dental literature, the present investigation evaluated three important physicochemical properties of mouthwashes commer-

Table 1. Distribution of the mouthwashes according to the commercial brand, chemical composition and manufacturer.

\begin{tabular}{|c|c|c|}
\hline Commercial Brand & Active ingredient & Manufacturer \\
\hline Cepacol $®$ & Cetylpiridinium Chloride & Sanofi-Aventis Farmacêutica Ltda. \\
\hline Clinerize ${ }^{\circledR}$ & Thymol & Lipson Cosméticos Ltda. \\
\hline Equate ${ }^{\circledR}$ & Cetylpiridinium Chloride & Ind. Com. Poli Products Ltda. \\
\hline Listerine Cool Citrus ${ }^{\circledR}$ & Thymol & Laboratórios Pfizer Ltda. \\
\hline Oral-B® & Cetylpiridinium Chloride & Gillette do Brasil Ltda. \\
\hline Periogard $\circledast$ & Chlorhexidine Gluconate & Colgate-Palmolive Argentina SA. \\
\hline Peroxyl@ & Hydrogen Peroxide & Colgate-Palmolive Ind. Com. \\
\hline Plax Overnight ${ }^{\circledR}$ & Cetylpiridinium Chloride & Colgate-Palmolive Ind. Com. Ltda. \\
\hline Prevident $220 \AA$ & Cetylpiridinium Chloride & Colgate-Palmolive Argentina SA. \\
\hline Sanifill $®$ & Cetylpiridinium Chloride & $\begin{array}{l}\text { Facilit Odontológica e Perfumaria } \\
\text { Ltda. }\end{array}$ \\
\hline
\end{tabular}


cially available in Brazil: $\mathrm{pH}$, titratable acidity, and ${ }^{\circ} \mathrm{Bx}$. Although a $\mathrm{pH}$ value equal to or less than 5.5 is considered critical for enamel dissolution, mineral loss may begin even at higher $\mathrm{pH}_{;}{ }^{6}$ therefore, the prolonged use of oral rinses with $\mathrm{pH}$ below this value may be potentially harmful to dental tissue. In the present study, three mouthwashes were classified as potentially erosive $(\mathrm{pH}<5.5)$, corroborating the findings of previous investigations. ${ }^{2,45,5,8,10}$ The low $\mathrm{pH}$ of oral care products increases the chemical stability of some fluoride compounds and favors the incorporation of fluoride ions into the lattice of hydroxyapatite and the precipitation of calcium fluoride onto the tooth surface. ${ }^{11}$ Based on this statement, product labels were examined to identify mouthwashes containing fluoride. Among the three mouthwashes with $\mathrm{pH}$ less than 5.5, only Oral-B® has fluoride $(0.05 \% \mathrm{NaF})$ in its formulation. The label of the other two mouthwashes with $\mathrm{pH}$ below the critical value for enamel dissolution (Listerine Cool Citrus $\AA$ and Periogard $®$ ) did not list fluoride in their ingredients. Lack of fluoride and low $\mathrm{pH}$ may make these products harmful to dental tissues if not used carefully. Although mouthrinses have been formulated as pre- and post-brushing products for routine use, findings of a previous in situ study evaluating the erosive effects of some mouthrinses on enamel have sug- gested that low $\mathrm{pH}$ mouthrinses should not be considered for long-term or continuous use and never as pre-brushing rinses; ${ }^{8}$ however, it must be emphasized that erosive potential of a substance cannot be attributed exclusively to $\mathrm{pH} .{ }^{4}$ Other important physicochemical properties, such titratable acidity, ${ }^{\circ} \mathrm{Bx}$, and viscosity, should be also be considered. In this study, titratable acidity determined the amount of acid present and the volume of $\mathrm{KOH}$ necessary to buffer the test solution, a characteristic directly related to the buffering capacity of the saliva. Substances with low titratable acidity are readily neutralized by oral fluids, while those with high titratable acidity cause a prolonged drop in $\mathrm{pH}$ and greater demineralization of dental tissues. ${ }^{12}$ In the present study, Prevident $220 \AA$ exhibited high titratable acidity even with $\mathrm{pH}$ close to 6. A possible explanation for this result is that some ingredients present in its composition did not react with the base used to neutralize the mouthwash $(0.1 \mathrm{~N} \mathrm{KOH})$. Four of the mouthwashes exhibited ${ }^{\circ} \mathrm{Bx}$ greater than $20 \%$, that is, $20 \mathrm{~g}$ of solids dissolved in $100 \mathrm{~g}$ of mouthwash. Among the tested mouthwashes, Clinerize ${ }^{\circledR}$ presented the highest ${ }^{\circ} \mathrm{Bx}$. Lack of similar studies evaluating ${ }^{\circ} \mathrm{Bx}$ of oral rinse products hinders comparison of the present results to data published in the literature. Brix refractometry is a physical method for mea-

Table 2. Distribution of the mouthwashes according to the mean values and standard deviations for endogenous $\mathrm{pH}$, titratable acidity and total soluble solid content (TSSC).

\begin{tabular}{|c|c|c|c|c|c|c|}
\hline \multirow{2}{*}{ Commercial brand } & \multicolumn{2}{|c|}{ Endogenous $\mathrm{pH}$} & \multicolumn{2}{|c|}{ Titratable acidity } & \multicolumn{2}{|c|}{ TSSC } \\
\hline & Mean & SD & Mean & SD & Mean & SD \\
\hline Cepacol $\circledast$ & 7.43 & \pm 0.13 & 0.04 & \pm 0.01 & $9.8 \%$ & \pm 0.52 \\
\hline Clinerize ${ }^{\circledR}$ & 4.51 & \pm 0.12 & 0.009 & \pm 0.00 & $23.7 \%$ & \pm 0.43 \\
\hline Equate $®$ & 6.70 & \pm 0.22 & 0.02 & \pm 0.00 & $20.0 \%$ & \pm 0.0 \\
\hline Listerine Cool Citrus ${ }^{\circledR}$ & 4.16 & \pm 0.13 & 0.07 & \pm 0.01 & $22.7 \%$ & \pm 0.28 \\
\hline Oral-B® & 5.79 & \pm 0.22 & 0.04 & \pm 0.01 & $4.7 \%$ & \pm 0.0 \\
\hline Periogard $\circledast$ & 5.92 & \pm 0.23 & 0.007 & \pm 0.00 & $12.1 \%$ & \pm 0.28 \\
\hline Peroxyl@ & 3.56 & \pm 0.06 & 0.05 & \pm 0.01 & $14.0 \%$ & \pm 0.0 \\
\hline Plax Overnight ${ }^{\circledR}$ & 6.20 & \pm 0.15 & 0.009 & \pm 0.00 & $16.7 \%$ & \pm 0.0 \\
\hline Prevident $220 \AA$ & 5.90 & \pm 0.03 & 0.53 & \pm 0.03 & $20.91 \%$ & \pm 0.14 \\
\hline Sanifill® & 6.36 & \pm 0.09 & 0.09 & \pm 0.00 & $7.9 \%$ & \pm 0.14 \\
\hline
\end{tabular}


suring the amount of soluble solids (sugar, salts, proteins, acids, etcl present in an aqueous solution. ${ }^{13}$ The majority of medicinal formulations, if not all, have some side effects, whether local or systemic. In each case, it is important to assess the benefit-to-risk ratio. Risk clearly will be influenced by the likely incidence and severity of side effects. In the case of dental erosion, the regimen and duration of use of a potentially erosive agent will be critical to the outcome. Mouthwashes in general have similar regimens of use, namely $10-$ $20 \mathrm{~mL}$ rinsed twice a day for 30-60 seconds. It is recommended that low $\mathrm{pH}$ oral rinse products be used as short to medium term adjuncts to oral hygiene and never as prebrushing rinses. ${ }^{8}$

\section{CONCLUSIONS}

The findings of this investigation cannot be directly extrapolated to the clinical situation; however, results indicate that some of the mouthwashes evaluated exhibited low endogenous $\mathrm{pH}$, even below the critical value for enamel dissolution (5.5), high titratable acidity, and high total soluble solid content, which may make these products potentially erosive to dental tissue if not properly used.

\section{REFERENCES}

1. Thylstrup A, Fejerskov 0. Textbook of Clinical Cariology. 2nd ed. Munksgaard: Copenhagen, 1994.

2. Corso S, Corso, AC, Hugo FN, Padilha DMP. Evaluation of the erosive potencial of oral mouthwashes. Rev Odonto Ciênc 2004;19:233-237.

3. Watson IB, Tulloch EN. Clinical assessment of cases of tooth surface loss. Br Dent J 1985;159:144-148.

4. Lima AL, Valença AMG, Albuquerque FR, Silva NB. Analysis of $\mathrm{pH}$ and viscosity of commercially available fluoride mouthrinses in the city of João Pessoa/PB. Pesq Bras Odontoped Clin Integr 2005;5:223-228.

5. Bhatti SA, Walsh TF, Douglas CW. Ethanol and pH levels of proprietary mouthrinses. Community Dent Health 1994;11:71-74.

6. Birkhed D. Sugar content, acidity and effect on plaque $\mathrm{pH}$ of fruit juices, fruit drinks, carbonated beverages and sports drinks. Caries Res 1984;18:120-127.

7. Adams D, Addy M. Mouthrinses. Adv Dent Res 1994;8:291301.

8. Pontefract $\mathrm{H}$, Hughes J, Kemp K, Yates R, Newcombe RG, Addy M. The erosive effects of some mouthrinses on enamel. A study in situ. J Clin Periodontol 2001;28:319-324.
9. Pretty IA, Edgar WM, Higham SM. The erosive potential of commercially available mouthrinses on enamel as measured by Quantitative Light-induced Fluorescence (QLF). $J$ Dent 2003;31:313-319.

10. Perdok JF, van der Mei HC, Busscher HJ. Physicochemical properties of commercially available mouthrinses. J Dent 1990;18:147-150.

11. Hellwig E, Lussi A. Oral hygiene products and acidic medicines. Monogr Oral Sci 2006;20:112-118.

12. Costa CC, Almeida ICS, Raymundo MS, Fett R. Analysis of the endogenous $\mathrm{pH}$, acidity and sucrose concentration in pediatric medicines. Rev Odonto Ciênc 2004;19:164-169.

13. Ball DW. Concentration scales for sugar solutions. J Chem Educ 2006;83:1489-1491. 